\section{Use of Species-specific Controlled-release Fertilizer Rates to Manage Growth and Quality of Container Nursery Crops}

\author{
Mary Jane Clark ${ }^{1}$ and Youbin Zheng ${ }^{2,3}$
}

ADDITIONAL INDEX WORDs. mineral nutrition, nitrogen, growing substrate, $\mathrm{pH}$, deficiency

SUMMARY. The objective of this study was to determine the optimal controlledrelease fertilizer (CRF) application rates or ranges for the production of five 2-gal nursery crops. Plants were evaluated following fertilization with $19 \mathrm{~N}-2.6 \mathrm{P}-10.8 \mathrm{~K}$ plus minors, 8-9 month CRF incorporated at $0.15,0.45,0.75,1.05,1.35$, and $1.65 \mathrm{~kg} \cdot \mathrm{m}^{-3}$ nitrogen $(\mathrm{N})$. The five crops tested were bigleaf hydrangea (Hydrangea macrophylla), 'Green Velvet' boxwood (Buxus $\times$ ), 'Magic Carpet' spirea (Spiraea japonica), 'Palace Purple' coral bells (Heuchera micrantha), and rose of sharon (Hibiscus syriacus). Most plant growth characteristics (i.e., growth index, plant height, leaf area, and shoot dry weight) were greater in high vs. low CRF treatments at the final harvest. Low CRF rates negatively impacted overall appearance and marketability. The species-specific CRF range recommendations were 1.05 to 1.35 $\mathrm{kg} \cdot \mathrm{m}^{-3} \mathrm{~N}$ for rose of sharon, 0.75 to $1.05 \mathrm{~kg} \cdot \mathrm{m}^{-3} \mathrm{~N}$ for 'Magic Carpet' spirea, and 0.75 to $1.35 \mathrm{~kg} \cdot \mathrm{m}^{-3} \mathrm{~N}$ for bigleaf hydrangea and 'Green Velvet' boxwood, whereas the recommended CRF rate for 'Palace Purple' coral bells was $0.75 \mathrm{~kg} \cdot \mathrm{m}^{-3} \mathrm{~N}$. Overall, species-specific CRF application rates can be used to manage growth and quality of containerized nursery crops during production in a temperate climate.

$\mathrm{T}$ o meet growing consumer demand for nursery crops in North America, container nursery crop production has intensified over the last 30 years (Davidson et al., 1988; Statistics Canada, 2013; U.S. Department of Agriculture, 2006). Container-grown nursery crops in North America and worldwide, are commonly produced using CRFs owing to the benefits derived from this fertilization method, such as reduced labor costs and improved nutrient use efficiency (Alam et al., 2009; Chen et al., 2001, 2011; Yeager and Cashion, 1993). Manufacturerrecommended CRF application rates are usually determined under constant laboratory or greenhouse conditions (Birrenkott et al., 2005; Cabrera,

\footnotetext{
This work was financially supported by Agriculture and Agri-Food Canada through the Canadian Agricultural Adaptation Program (CAAP), Landscape Ontario, and Agrium Advanced Technologies.

Thanks to our Niagara peninsula nursery partner for providing materials, time and expertise. The authors thank Erin Agro for the informative discussions during the preparation of this manuscript and technical assistance during the experiment; and Tim Moffat for his technical assistance.

${ }^{1}$ Vineland Research and Innovation Centre, 4890 Victoria Avenue North, Box 4000, Vineland Station, ON, L0R 2E0, Canada

${ }^{2}$ School of Environmental Sciences, University of Guelph, 50 Stone Road East, Guelph, ON, NIG 2Wl, Canada

${ }^{3}$ Corresponding author. E-mail: yzheng@uoguelph.
} ca.

1997; Oliet et al., 2004) and commonly do not include environmental fluctuations that are experienced in outdoor nursery crop production. Unlike relatively stable greenhouse environments, variable temperature and rainfall conditions in outdoor nursery environments may influence both the CRF release rate and crop fertility requirements, which directly impact nursery crop management strategies (Agro, 2014; Agro and Zheng, 2014; Cabrera, 1996; Zheng et al., 2010). To recommend appropriate fertilization strategies to manage nursery crops, region- and climate-specific studies are needed.

Although fertilizer companies continually develop new products, testing these products outdoors in region-specific studies at commercial nursery sites has been limited. Previous studies were mainly restricted to a few plant species, select fertilizer types differing in nutrient sources, and coating technology (e.g., Nutricote; Chisso-Asahi Fertilizer Co., Tokyo, Japan), or conducted in warm climates (e.g., Florida) for a short duration (Chen et al., 2001; Griffin et al., 1999; Ruter, 1992; Yeager and Cashion, 1993). Only a few temperateregion studies (i.e., in Canada and northeastern United States) with a limited number of crops, CRF rates, and types, have evaluated CRF applications for container nursery crop production (Agro, 2014; Agro and Zheng, 2014; Clark and Zheng, 2015; Hicklenton and Cairns, 1992; Lumis and Taurins, 2000). To build and expand on these past studies, further research at commercial nurseries is needed to develop fertilization recommendations to manage the growth and quality of different nursery crops in a range of environments.

Currently, it is standard practice to use generalized CRF application rates (i.e., not species-specific) at nurseries. However, under-fertilization can restrict nutrient availability, cause tissue nutrient deficiencies, limit plant growth or quality, and lengthen production time; whereas over-fertilization is expensive and may result in plant injury, pest and disease problems, and environmentally damaging nutrient leaching (Agro, 2014; Majsztrik et al., 2011; Yeager et al., 1993). As individual plant species and cultivars have unique nutrient requirements, customizing CRF application rates per species is ideal for efficient, environmentally conscious, high-quality plant production (Britton et al., 1998; Cabrera, 2003; Chen et al., 2001, 2011; Timmer and Aidelbaum, 1996).

\begin{tabular}{llll}
\hline $\begin{array}{l}\text { Units } \\
\begin{array}{l}\text { To convert U.S. to SI, } \\
\text { multiply by }\end{array}\end{array}$ & U.S. unit & SI unit & $\begin{array}{l}\text { To convert SI to U.S., } \\
\text { multiply by }\end{array}$ \\
\hline 29.5735 & $\mathrm{fl} \mathrm{oz}$ & $\mathrm{mL}$ & 0.0338 \\
3.7854 & gal & $\mathrm{L}$ & 0.2642 \\
2.54 & inch(es) & $\mathrm{cm}$ & 0.3937 \\
25.4 & inch(es) & $\mathrm{mm}$ & 0.0394 \\
6.4516 & inch $^{2}$ & $\mathrm{~cm}^{2}$ & 0.1550 \\
16.3871 & inch $^{3}$ & $\mathrm{~cm}^{3}$ & 0.0610 \\
16.0185 & lb $/ \mathrm{ft}^{3}$ & $\mathrm{~kg} \cdot \mathrm{m}^{-3}$ & 0.0624 \\
1 & $\mathrm{mmho} / \mathrm{cm}$ & $\mathrm{mS} \cdot \mathrm{cm}^{-1}$ & 1 \\
28.3495 & $\mathrm{Oz}$ & $\mathrm{g}$ & 0.0353 \\
1 & $\mathrm{ppm}$ & $\mathrm{mg} \cdot \mathrm{kg}^{-1}$ & 1 \\
$\left({ }^{\circ} \mathrm{F}-32\right) \div 1.8$ & ${ }^{\circ} \mathrm{F}$ & ${ }^{\circ} \mathrm{C}$ & $\left({ }^{\circ} \mathrm{C} \times 1.8\right)+32$
\end{tabular}


Such species-specific CRF application rate recommendations are necessary, especially during this era of nursery best management practices and environmental sustainability (Yeager et al., 2010). Therefore, the objectives of this study were to determine if application rates for CRFs can be used to optimize nursery crop growth under temperate climate conditions, and to determine specific CRF rate or range recommendations for nursery production of five 2 -gal container-grown nursery crops.

\section{Materials and methods}

PLANT MATERIAL AND FERTILIZATION. At a wholesale nursery located in the Niagara Peninsula, ON, Canada (lat. $43.01^{\circ} \mathrm{N}$, long. $79.38^{\circ} \mathrm{W}$ ), five commonly grown nursery crops were selected for study, based on their economic value and relative importance to Ontario nurseries: bigleaf hydrangea, 'Green Velvet' boxwood, 'Magic Carpet' spirea, 'Palace Purple' coral bells, and rose of sharon. Ten liners for each species (initially grown in 4-inch-wide square pots for 'Palace Purple' coral bells, round 51/2-inchdiameter pots for 'Green Velvet' boxwood, and round 5-inch-diameter pots for the remaining species), per CRF rate $(n=10)$ were planted into $5.75 \mathrm{~L}$ of growing substrate in round trade 2 -gal black plastic containers $(22-\mathrm{cm}$ diameter $\times 21.5-\mathrm{cm}$ height $)$ on 15 May 2013 following the nursery's standard production practices. For all species except 'Palace Purple' coral bells, which had an addition of perlite (PVP Industries, North Bloomfield, $\mathrm{OH}$ ), a proprietary growing substrate was used, consisting of pine bark (Growers Choice, Kitchener, ON, Canada) and Canadian sphagnum peatmoss (Growers Grade White; Sun Gro, Maisonnette, NB, Canada). At planting, the substrate had a $\mathrm{pH}$ of 5.2 and an electrical conductivity (EC) of $0.6 \mathrm{mS} \cdot \mathrm{cm}^{-1}$, whereas the perlite-amended substrate had a $\mathrm{pH}$ of 5.8 and an EC value of $0.6 \mathrm{mS} \cdot \mathrm{cm}^{-1}$. Nutrient levels in the substrates with and without perlite were as follows: $1.0 \mathrm{mg} \cdot \mathrm{kg}^{-1}$ nitrate for both, $<0.5$ $\mathrm{mg} \cdot \mathrm{kg}^{-1}$ ammonium for both, 2.8 and $4.5 \mathrm{mg} \cdot \mathrm{kg}^{-1}$ phosphorus (P), 18.3 and $29.0 \mathrm{mg} \cdot \mathrm{kg}^{-1}$ potassium $(\mathrm{K}), 4.3$ and $6.7 \mathrm{mg} \cdot \mathrm{kg}^{-1}$ magnesium $(\mathrm{Mg})$, and 12.5 and $21.4 \mathrm{mg} \cdot \mathrm{kg}^{-1}$ calcium $(\mathrm{Ca})$, respectively, as analyzed using a saturated paste extraction method (SGS Agri-Food Laboratories, Guelph, ON,
Canada). A 19N-2.6P-10.8K CRF (Polyon ${ }^{\circledR}$ 19-06-13 plus minors, 8-9 months; Agrium Advanced Technologies, Calgary, $\mathrm{AB}$, Canada) was incorporated into the growing substrate for each pot by hand at rates of $0.15,0.45$, $0.75,1.05,1.35$, or $1.65 \mathrm{~kg} \cdot \mathrm{m}^{-3}$ nitrogen. The guaranteed minimum analysis of this CRF is $8.09 \%$ ammonical N, $7.16 \%$ nitrate $\mathrm{N}, 3.75 \%$ urea $\mathrm{N}$, $6.00 \%$ phosphoric acid, $13.00 \%$ soluble potash, $4.70 \%$ sulfur, $1.00 \% \mathrm{Mg}$ of which $0.5 \%$ is water soluble, $1.18 \%$ soluble iron, $0.02 \%$ chelated iron, $0.099 \%$ manganese of which $0.079 \%$ is water soluble, $0.0019 \%$ water soluble molybdenum, $0.099 \%$ zinc of which $0.079 \%$ is water soluble, and $0.099 \%$ copper of which $0.079 \%$ is water soluble (Agrium Advanced Technologies). Fertilizer rates were selected based on general recommendations for nursery crops made by Agrium Advanced Technologies (i.e., $4-10 \mathrm{~kg} \cdot \mathrm{m}^{-3}$ ), nursery grower suggestions, and earlier studies (Agro, 2014; Agro and Zheng, 2014; Alam et al., 2009). Pots were weeded monthly and production practices and overhead sprinkler irrigation scheduling were followed as per standard production practices for the nursery. Irrigation frequency and amount was grower-determined, based on environmental conditions and water use by plants. Irrigation water was drawn from an on-site catchment pond during the study. In addition to irrigation, total monthly precipitation for the region was $77.9,144.2,48.5,78.1$, and $73.0 \mathrm{~mm}$ in May, June, July, Aug., and Sept. 2013, respectively (Environment Canada, 2013). Monthly mean minimum and maximum air temperatures were 8.3 to $21.7,13.7$ to 22.7 , 17.0 to $26.4,13.6$ to 25.0 , and 9.3 to $20.8^{\circ} \mathrm{C}$ in May, June, July, Aug., and Sept. 2013, respectively (Environment Canada, 2013).

EXPERIMENTAL DESIgN. Plants were arranged in a randomized block design, grouped by species, on a welldrained gravel plot outdoors at the nursery. Ten plants (replications) of each fertilizer rate treatment were randomly arranged with $\approx 10 \mathrm{~cm}$ of space between pots, to reduce shading within the block. Plants within blocks were rerandomized monthly to reduce location error. The production area was bordered with at least one row of unmeasured plants to reduce perimeter effects.

Measurements. Leachate $\mathrm{pH}$ and $\mathrm{EC}$ as well as plant growth measurements were made monthly between May and Sept. 2013, which coincides with the growing season in Ontario. Irrigation water was sampled monthly from an on-site catchment pond $(n=3)$. Collected leachate and irrigation water was evaluated for $\mathrm{pH}$ and $\mathrm{EC}$ using a portable $\mathrm{pH}$ and $\mathrm{EC}$ meter (PC 300; Oakton Instruments, Vernon Hills, IL). Irrigation water from the on-site catchment pond had an EC of 0.6, 0.6, 0.9, 1.2, and $1.5 \mathrm{mS} \cdot \mathrm{cm}^{-1}$ and a $\mathrm{pH}$ of $7.9,7.6$, $7.5,7.5$, and 7.5 in May, June, July, August, and September, respectively. Plant growth was evaluated during the growing season by measuring plant height and canopy width, in two perpendicular directions, for seven representative liners per species at planting, for five plants per species per CRF rate treatment $\mathrm{l}$ week after planting and monthly thereafter. Aboveground plant growth index was calculated as [ (height $\times$ width $_{1} \times$ width $\left._{2}\right) \div 300$ ], as outlined by Ruter (1992). Growing substrate $\mathrm{pH}$ and EC were measured for five plants per species per treatment 1 week after planting and monthly, thereafter, until Sept. 2013 using the pourthrough method (Wright, 1986). The pour-through method was conducted by irrigating plants to saturation, waiting $\approx \mathrm{l}$ h, adding $200 \pm 50$ $\mathrm{mL}$ of reverse osmosis water to each container and collecting leachate for analysis. Toward the end of the 2013 growing season, before cool fall air temperatures and leaf senescence began (i.e., on 13 Sept. 2013), all species and treatments were evaluated by industry professionals to determine which plants had reached marketable size. In addition, five plants per species per treatment were ranked from 1 (worst) to 5 (best) for overall appearance among all treatments, relative to plants of the same species. Overall appearance ranking values and marketability were visually assessed based on foliage density, plant symmetry, leaf size and color, number of stems, and amount of branching, as these measures of quality are based on aesthetic appeal and consumer approval (Stroup et al., 1998). A satisfactory overall appearance threshold was determined per species by the grower, according to market demands. Leaf area was measured for five plants per species per CRF rate using a leaf area meter (LI-3100; LI-COR, Lincoln, NE) at the end of 
the growing season (Sept. 2013). Stems and leaves from individual plants were dried at $70{ }^{\circ} \mathrm{C}$ until a constant weight was achieved. Shoot dry weight was calculated as the sum of stem and leaf tissue dry weight per plant. Dried leaves were analyzed for tissue $\mathrm{N}$ (percent dry weight) by SGS Agri-Food Laboratories using a combustion method, with $\mathrm{N}$ gases quantified by thermal conductivity [AOAC method 990.03 (TruSpec; LECO Instruments, St. Joseph, MI)]. Leaf tissue $\mathrm{P}, \mathrm{K}, \mathrm{Mg}$, and $\mathrm{Ca}$ concentrations were analyzed from ashed samples solubilized in hydrochloric acid by inductively coupled plasma via emission spectroscopy [AOAC method 985.01, SGS AgriFood Laboratories (OPTIMA 8300 OES; Perkin Elmer, Shelton, CT)].

Statistical analysis. All data sets were analyzed using GraphPad Prism software (version 5.03; GraphPad Software, La Jolla, CA). Data were subject to a one-way analysis of variance (ANOVA) for shoot dry weight, plant height, leaf area, and tissue nutrient concentration with differences among means determined according to Tukey's multiple comparison test. Overall appearance data were analyzed with a nonparametric Kruskal-Wallis test and a Dunn's multiple comparison test. A twoway repeated measures ANOVA with a Bonferroni post test was used to evaluate differences among CRF rate treatments and time points for growth index, leachate $\mathrm{EC}$, and $\mathrm{pH}$ for each nursery crop. Regression analyses with extra sum-of-squares $\mathrm{F}$ tests were used to relate growth index and leaf nutrient concentration to CRF rate over time and to estimate regression parameters for the best-fit regression model. Pearson correlation coefficients $(r)$ were calculated to compare CRF rate with $\mathrm{pH}$ and $\mathrm{EC}$ $(n=5)$ and leaf dry weight and CRF rate with leaf tissue nutrient concentration $(n=3)$. Leachate $\mathrm{pH}$ in September was analyzed with a one sample $t$ test, with means per CRF rate $(n=5)$ compared with the upper $\mathrm{pH}$ limit for healthy plant growth [6.25 (Reed, 1996)]. All data were evaluated using a significance level of $P<0.05$.

\section{Results}

Plant Quality. Considering plant quality observations and evaluations carried out by industry professionals, the overall appearance of most species differed according to the CRF rate used (Fig. 1). For the majority of species, high CRF rates produced plants with the best overall appearance. 'Magic Carpet' spirea was a notable exception with a lower overall appearance at 1.65 than 1.05 and $1.35 \mathrm{~kg} \cdot \mathrm{m}^{-3} \mathrm{~N}$. The lowest CRF rates that produced plants with satisfactory quality and a marketable size by 13 Sept. 2013 were $1.05 \mathrm{~kg} \cdot \mathrm{m}^{-3} \mathrm{~N}$ for rose of sharon and $0.75 \mathrm{~kg} \cdot \mathrm{m}^{-3} \mathrm{~N}$ for 'Palace Purple' coral bells, bigleaf hydrangea, and 'Magic Carpet' spirea (Fig. 1). 'Green Velvet' boxwood did not reach marketable size for any CRF rate by Sept. 2013, as this is usually a 2 -year crop at this nursery. In addition to plant form, size and leaf color, nursery crop quality was influenced by flowering. In Aug. and Sept. 2013, greater flowering was observed for 'Magic Carpet' spirea and rose of sharon at high vs. low CRF rates. Only one 'Palace Purple' coral bells plant, grown at $1.65 \mathrm{~kg} \cdot \mathrm{m}^{-3} \mathrm{~N}$, flowered during the study and no bigleaf hydrangea plants flowered.

Plant growth AND LEAF NUTRIENT CONCENTRATION. Similar to the overall appearance observations, growth index, plant height, leaf area, and shoot dry weight were greater at high vs. low CRF rates for the majority of nursery crops in Sept. 2013 (Fig. 1; Table 1). Over time from May to Sept. 2013, regression analyses indicated a significant increase in growth index for rose of sharon, bigleaf hydrangea, and 'Magic Carpet' spirea grown at all CRF rates, 'Palace Purple' coral bells grown at all but $0.15 \mathrm{~kg} \cdot \mathrm{m}^{-3} \mathrm{~N}$, and 'Green Velvet' boxwood grown at all but 0.15 and $0.45 \mathrm{~kg} \cdot \mathrm{m}^{-3} \mathrm{~N}$ (Table 2).

At harvest (Sept. 2013), leaf N concentration was greater at high vs. low CRF rates for bigleaf hydrangea, 'Magic Carpet' spirea, 'Palace Purple' coral bells, and rose of sharon (Table 3). A significant linear or quadratic regression was observed for bigleaf hydrangea and 'Palace Purple' coral bells among CRF rates in Sept. 2013 for leaf $\mathrm{N}, \mathrm{P}, \mathrm{K}, \mathrm{Mg}$, and Ca concentrations, whereas a significant regression among CRF rates was observed for at least three of the evaluated nutrients for 'Green Velvet' boxwood, 'Magic Carpet' spirea, and rose of sharon (Table 3). Leaf $\mathrm{N}$ concentration was positively correlated with CRF rate for bigleaf hydrangea, 'Magic Carpet' spirea, 'Palace Purple' coral bells, and rose of sharon. Leaf $\mathrm{P}$ concentration was the greatest at $0.15 \mathrm{~kg} \cdot \mathrm{m}^{-3} \mathrm{~N}$ for rose of sharon and 'Magic Carpet' spirea, and a significant increase in leaf $\mathrm{P}$ concentration was observed with increasing CRF rate for 'Palace Purple' coral bells and bigleaf hydrangea. Leaf $\mathrm{K}$ concentration significantly increased with increasing CRF rate for bigleaf hydrangea, 'Green Velvet' boxwood, and 'Magic Carpet' spirea and leaf K concentration was greatest at midrange CRF rates for 'Palace Purple' coral bells. With increasing CRF rate, leaf $\mathrm{Mg}$ concentration significantly increased for 'Palace Purple' coral bells and bigleaf hydrangea, but decreased for 'Green Velvet' boxwood. Leaf Ca concentration was positively correlated with CRF rate for bigleaf hydrangea and negatively correlated with CRF rate for 'Green Velvet' boxwood. In addition, we also observed correlations between leaf dry weight and leaf nutrient concentration. Leaf dry weight was positively correlated with the following leaf nutrient concentrations for certain crops: N ['Palace Purple' coral bells, rose of sharon and bigleaf hydrangea $(r=0.80,0.66$, and 0.80 , respectively)], P ['Green Velvet' boxwood, 'Palace Purple' coral bells, and bigleaf hydrangea $(r=0.58,0.55$, and 0.78 , respectively)], K ['Green Velvet' boxwood, 'Palace Purple' coral bells, bigleaf hydrangea, and 'Magic Carpet' spirea $(r=0.76,0.56,0.61$, and 0.67 , respectively)], $\mathrm{Mg}$ [bigleaf hydrangea $(r=0.74)$ ] , and $\mathrm{Ca}$ [bigleaf hydrangea $(r=0.50)]$. In contrast, negative correlations occurred between leaf dry weight and nutrient concentration for the following crops: $\mathrm{P}$ ['Magic Carpet' spirea $(r=-0.80)$ ], $\mathrm{Mg}$ ['Green Velvet' boxwood and 'Magic Carpet' spirea $(r=-0.73$ and -0.54 , respectively)], and $\mathrm{Ca}$ ['Green Velvet' boxwood and rose of sharon $(r=-0.81$ and -0.49 , respectively)].

At the nursery, nutrient disorders are often identified by leaf color changes; however, cultivar-specific standard leaf colors were red-purple and dark green for 'Palace Purple' coral bells, light green with yellow and red shoot tips for 'Magic Carpet' spirea, and green for all other species. In Sept. 2013, at $0.15 \mathrm{~kg} \cdot \mathrm{m}^{-3} \mathrm{~N}$ 'Palace Purple' coral bells leaves were small and dark red-purple, whereas bigleaf hydrangea leaves were light green and yellow with some purple leaf margins. At all CRF rates $>0.15$ 


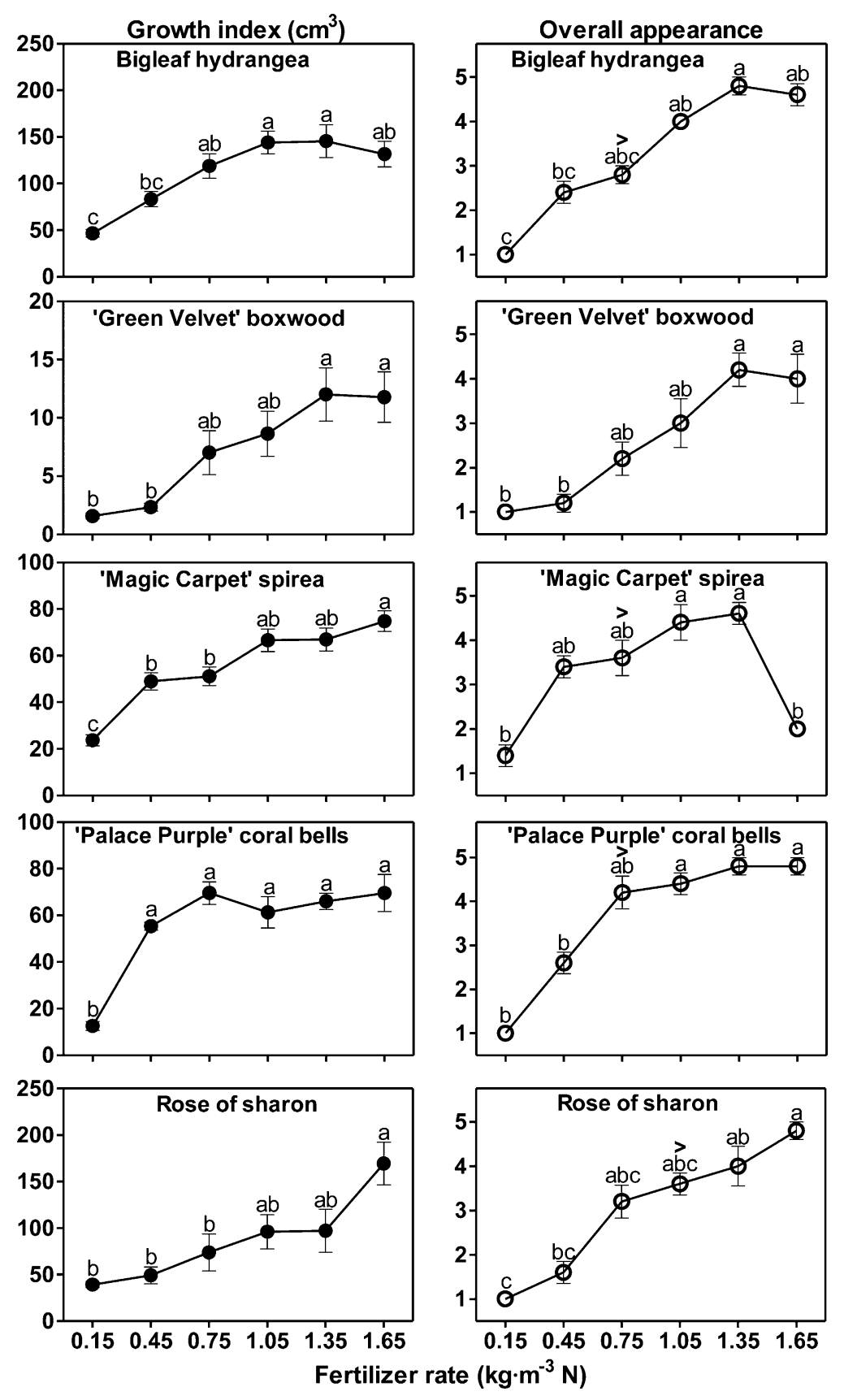

Fig. 1. Growth index and overall appearance for five container-grown nursery crops in Sept. 2013 following transplant on 15 May 2013 and fertilized with six rates of nitrogen $(\mathrm{N})$ incorporated from an 8-9 month release $19 \mathrm{~N}-2.6 \mathrm{P}-10.8 \mathrm{~K}$ plus minors, controlled-release fertilizer (CRF). Overall appearance ranking values were visually assessed on the scale of 1 (worst) to 5 (best), based on foliage density, plant symmetry, leaf size and color, number of stems, and amount of branching, as these measures of quality are based on aesthetic appeal and consumer approval (Stroup et al., 1998). Data are means $\pm \operatorname{SE}(n=5)$. Symbols bearing the same letter are not significantly different among CRF rates per characteristic per nursery crop, according to a one-way analysis of variance and Tukey's multiple comparison test at $P<0.05 ; 1 \mathrm{~kg} \cdot \mathrm{m}^{-3}=0.0624 \mathrm{lb} / \mathrm{ft}^{3}, 1 \mathrm{~cm}^{3}=0.0610$ inch $^{3}$.

$\mathrm{kg} \cdot \mathrm{m}^{-3} \mathrm{~N}$, 'Palace Purple' coral bells and bigleaf hydrangea leaves were green. 'Magic Carpet' spirea leaves were lighter yellow at 0.15 and 1.65 $\mathrm{kg} \cdot \mathrm{m}^{-3} \mathrm{~N}$ than at all other CRF rates in Sept. 2013 and 'Magic Carpet' spirea grown at $1.65 \mathrm{~kg} \cdot \mathrm{m}^{-3} \mathrm{~N}$ had internal-canopy leaf dieback.

Leachate $\mathrm{PH}$ and EC. The mean leachate $\mathrm{pH}$ in May 2013 did not differ among CRF rates for individual nursery crops in the current study and ranged from 5.64 for 'Magic Carpet' spirea to 5.73 for bigleaf hydrangea. Significant positive correlations were observed in June 2013 between CRF rate and $\mathrm{pH}$ for bigleaf hydrangea, 'Magic Carpet' spirea, 'Palace Purple' coral bells, and rose of sharon $(r=0.93,0.98$, 0.97 , and 0.83 , respectively). However, negative correlations were observed in Sept. 2013 between CRF rate and $\mathrm{pH}$ for bigleaf hydrangea, 'Green Velvet' boxwood, 'Palace Purple' coral bells, and rose of sharon $(r=-0.93,-0.92,-0.86$, and -0.90 , respectively). In Sept. 2013, lower leachate $\mathrm{pH}$ was observed for high vs. low CRF rates for all crops; low $\mathrm{pH}$ ranged from 4.59 to 5.92 at 1.65 $\mathrm{kg} \cdot \mathrm{m}^{-3} \mathrm{~N}$ for 'Green Velvet' boxwood and 'Magic Carpet' spirea, respectively, whereas high $\mathrm{pH}$ ranged from 6.37 to 6.69 at $0.45 \mathrm{~kg} \cdot \mathrm{m}^{-3} \mathrm{~N}$ for rose of sharon and 'Palace Purple' coral bells, respectively. In May 2013, EC did not differ among CRF rates for three crops and averaged $0.79,0.88$, and $0.95 \mathrm{mS} \cdot \mathrm{cm}^{-1}$ for 'Green Velvet' boxwood, bigleaf hydrangea, and rose of sharon, respectively. The EC of 'Magic Carpet' spirea and 'Palace Purple' coral bells differed among CRF rates in May and ranged from 0.67 to 1.26 and 0.55 to $1.11 \mathrm{mS} \cdot \mathrm{cm}^{-1}$ for these crops, respectively. In June 2013, CRF rate was positively correlated to EC for bigleaf hydrangea, 'Green Velvet' boxwood, 'Magic Carpet' spirea, 'Palace Purple' coral bells, and rose of sharon $(r=0.88,0.96$, $0.84,0.94$, and 0.95 , respectively), but in Sept. 2013, only 'Green Velvet' boxwood EC was correlated to CRF rate $(r=0.94)$. By the end of the growing season (Sept. 2013), only the EC of rose of sharon did not differ among CRF rates with an average of $2.46 \mathrm{mS} \cdot \mathrm{cm}^{-1}$. The EC in Sept. 2013 of bigleaf hydrangea, 'Green Velvet' boxwood, 'Magic Carpet' spirea, and 'Palace Purple' coral bells among CRF rates ranged from 0.59 to $2.03,0.88$ to $4.84,0.31$ to 2.40 , and 0.29 to $2.11 \mathrm{mS} \cdot \mathrm{cm}^{-1}$, respectively.

\section{Discussion}

This study showed that applying CRF based on a species-specific rate or range may provide nursery growers with a management tool to promote plant growth, ensure plant quality, and prevent nutrient disorders during production. 
Table 1. Plant growth characteristics in Sept. 2013 for five May-planted container-grown nursery crops evaluated following one season of growth in the Niagara region of Ontario, Canada, produced with six rates of nitrogen $(\mathrm{N})$ incorporated from an $8-9$ month release $19 \mathrm{~N}-2.6 \mathrm{P}-10.8 \mathrm{~K}$ plus minors, controlled-release fertilizer (CRF).

\begin{tabular}{|c|c|c|c|}
\hline \multirow{2}{*}{ CRF rate $\left(\mathrm{kg} \cdot \mathrm{m}^{-3} \mathrm{~N}\right)^{\mathrm{z}}$} & $\mathrm{Ht}(\mathrm{cm})^{\mathrm{z}}$ & Leaf area $\left(\mathrm{cm}^{2}\right)^{\mathrm{z}}$ & Shoot dry wt $(\mathrm{g})^{\mathrm{z}}$ \\
\hline & \multicolumn{3}{|c|}{ mean $\pm \mathrm{SE}$} \\
\hline \multicolumn{4}{|l|}{ Bigleaf hydrangea } \\
\hline 0.15 & $18.6 \pm 0.7 \mathrm{~d}^{\mathrm{y}}$ & $1,318 \pm 176 \mathrm{~d}$ & $19.0 \pm 1.7 \mathrm{~d}$ \\
\hline 0.45 & $21.6 \pm 0.6 \mathrm{~cd}$ & $2,165 \pm 196 \mathrm{~cd}$ & $30.7 \pm 2.3 \mathrm{~cd}$ \\
\hline 0.75 & $26.4 \pm 1.3 \mathrm{ab}$ & $2,713 \pm 211 b c$ & $35.5 \pm 1.8 \mathrm{bc}$ \\
\hline 1.05 & $30.3 \pm 0.3 \mathrm{a}$ & $3,940 \pm 391 \mathrm{ab}$ & $50.3 \pm 4.2 \mathrm{ab}$ \\
\hline 1.35 & $26.6 \pm 1.1 \mathrm{ab}$ & $4,911 \pm 489 a$ & $57.6 \pm 4.7 \mathrm{a}$ \\
\hline 1.65 & $25.0 \pm 0.9 \mathrm{bc}$ & $3,901 \pm 247 \mathrm{ab}$ & $54.0 \pm 3.3 \mathrm{a}$ \\
\hline \multicolumn{4}{|l|}{ 'Green Velvet' boxwood } \\
\hline 0.15 & $8.1 \pm 0.5 c$ & $78 \pm 4 c$ & $2.2 \pm 0.1 \mathrm{~d}$ \\
\hline 0.45 & $8.8 \pm 0.8 \mathrm{bc}$ & $109 \pm 9 \mathrm{bc}$ & $2.7 \pm 0.2 \mathrm{~d}$ \\
\hline 0.75 & $13.0 \pm 1.3 \mathrm{ab}$ & $166 \pm 21 b$ & $4.4 \pm 0.4 \mathrm{c}$ \\
\hline 1.05 & $16.0 \pm 1.4 \mathrm{a}$ & $239 \pm 14 a$ & $6.6 \pm 0.3 b$ \\
\hline 1.35 & $15.3 \pm 0.6 \mathrm{a}$ & $244 \pm 18 \mathrm{a}$ & $6.9 \pm 0.5 \mathrm{ab}$ \\
\hline 1.65 & $16.4 \pm 1.0 \mathrm{a}$ & $291 \pm 11 \mathrm{a}$ & $8.4 \pm 0.3 \mathrm{a}$ \\
\hline \multicolumn{4}{|l|}{ 'Magic Carpet' spirea } \\
\hline 0.15 & $14.8 \pm 1.1$ & $727 \pm 74 c$ & $10.7 \pm 0.5 \mathrm{c}$ \\
\hline 0.45 & $18.0 \pm 0.5$ & $1,778 \pm 83 b$ & $25.4 \pm 1.5 b$ \\
\hline 0.75 & $17.6 \pm 1.1$ & $1,976 \pm 110 a b$ & $27.7 \pm 1.2 \mathrm{ab}$ \\
\hline 1.05 & $17.8 \pm 0.3$ & $2,266 \pm 88 \mathrm{a}$ & $30.8 \pm 0.9 a$ \\
\hline 1.35 & $17.2 \pm 0.9$ & $2,372 \pm 111 a$ & $31.8 \pm 0.9 a$ \\
\hline 1.65 & $17.8 \pm 0.2$ & $1,559 \pm 182 b$ & $26.2 \pm 1.9 \mathrm{ab}$ \\
\hline \multicolumn{4}{|l|}{ 'Palace Purple' coral bells } \\
\hline 0.15 & $9.4 \pm 0.7 b$ & $771 \pm 70 \mathrm{c}$ & $10.9 \pm 1.0 \mathrm{~b}$ \\
\hline 0.45 & $16.8 \pm 0.6 \mathrm{a}$ & $2,258 \pm 107 b c$ & $30.1 \pm 0.9 \mathrm{a}$ \\
\hline 0.75 & $17.6 \pm 0.5 \mathrm{a}$ & $2,665 \pm 25 \mathrm{ab}$ & $32.8 \pm 1.3 \mathrm{a}$ \\
\hline 1.05 & $16.2 \pm 0.9 a$ & $2,779 \pm 259 \mathrm{ab}$ & $33.7 \pm 3.0 \mathrm{a}$ \\
\hline 1.35 & $17.0 \pm 0.4 \mathrm{a}$ & $2,996 \pm 67 a$ & $34.1 \pm 1.7 \mathrm{a}$ \\
\hline 1.65 & $16.8 \pm 0.9 \mathrm{a}$ & $2,998 \pm 151 \mathrm{a}$ & $36.1 \pm 2.3 \mathrm{a}$ \\
\hline \multicolumn{4}{|l|}{ Rose of sharon } \\
\hline 0.15 & $31.0 \pm 1.4 \mathrm{c}$ & $258 \pm 24 \mathrm{~d}$ & $10.4 \pm 0.6 \mathrm{c}$ \\
\hline 0.45 & $35.8 \pm 3.4 \mathrm{bc}$ & $413 \pm 60 \mathrm{~cd}$ & $17.3 \pm 2.6 \mathrm{c}$ \\
\hline 0.75 & $52.6 \pm 6.7 \mathrm{ab}$ & $600 \pm 63 \mathrm{bcd}$ & $20.8 \pm 1.0 \mathrm{bc}$ \\
\hline 1.05 & $55.4 \pm 1.8 \mathrm{ab}$ & $929 \pm 43 \mathrm{bc}$ & $37.4 \pm 1.4 \mathrm{ab}$ \\
\hline 1.35 & $54.2 \pm 5.3 \mathrm{ab}$ & $1,037 \pm 195 \mathrm{ab}$ & $34.8 \pm 6.5 \mathrm{ab}$ \\
\hline 1.65 & $66.0 \pm 6.4 \mathrm{a}$ & $1,515 \pm 188 \mathrm{a}$ & $49.5 \pm 4.6 \mathrm{a}$ \\
\hline
\end{tabular}

${ }^{2} 1 \mathrm{~kg} \cdot \mathrm{m}^{-3}=0.0624 \mathrm{lb} / \mathrm{ft}^{3}, \mathrm{l} \mathrm{cm}=0.3937 \mathrm{inch}, \mathrm{l} \mathrm{cm}{ }^{2}=0.1550 \mathrm{inch}^{2}, \mathrm{lg}=0.0353 \mathrm{oz}$.

"Data for each species in the same column followed by the same letters are not significantly different, according to a one-way analysis of variance and Tukey's multiple comparison test at $P<0.05(n=5)$.

One benefit of applying speciesspecific CRF rates to manage nursery crop production may be reduced production time (Clark and Zheng, $2014,2015)$. Based on results from this study, potential CRF-influenced crop production time savings were determined by interpolating the September growth index value at the CRF rate, which produced marketablesized plants with higher CRF rates, as calculated from the regression equation of growth index over time (Fig. 1; Table 2). Selection of a species-specific CRF application rate had the potential to reduce crop production time (e.g., by $55 \mathrm{~d}$ for rose of sharon grown at $1.65 \mathrm{~kg} \cdot \mathrm{m}^{-3} \mathrm{~N}$ compared with $\left.1.05 \mathrm{~kg} \cdot \mathrm{m}^{-3} \mathrm{~N}\right)$. When high CRF application rates shorten the nursery crop production time, the total amount of nutrients leached may be reduced, compared with a longer production time. With a short production time, any nutrients remaining in the root zone, after production is complete, can be used by the nursery crop for additional shoot and root growth, once planted in the landscape. In addition, by applying species-specific CRF rates, nursery growers may have the opportunity to sell a crop sooner than if a generalized CRF rate was applied and may save ongoing crop input costs (e.g., labor, irrigation, etc.). Further research is needed to specifically quantify the cost savings of reduced production time following species-specific CRF application rates.

As plant growth response to increasing CRF rate usually follows a classic curve, poor growth results from either low, deficient CRF application rates (under-fertilization) or high, toxic CRF application rates [over-fertilization (Chen et al., 2001)]. However, at CRF rates between the deficient and toxic thresholds, a range of adequate fertilization occurs. Growth index of bigleaf hydrangea appeared to reach the adequate point of the growth curve at $0.75 \mathrm{~kg} \cdot \mathrm{m}^{-3} \mathrm{~N}$ and this was also the lowest CRF rate at which bigleaf hydrangea was marketable. For 'Green Velvet' boxwood in Sept. 2013 , growth index increased with increasing CRF rate, with no difference among higher CRF rates. These results indicate that higher CRF rates were adequate for the first year of this 2 -year 'Green Velvet' boxwood crop in this study. In Sept. 2013, 'Magic Carpet' spirea growth index increased with increasing CRF rate; however, overall appearance decreased from 1.35 to $1.65 \mathrm{~kg} \cdot \mathrm{m}^{-3} \mathrm{~N}$, indicating over-fertilization reduced plant quality from 1.35 to $1.65 \mathrm{~kg} \cdot \mathrm{m}^{-3} \mathrm{~N}$. Growth index of 'Palace Purple' coral bells in Sept. 2013 indicated adequate fertilization occurred at $0.45 \mathrm{~kg} \cdot \mathrm{m}^{-3}$ $\mathrm{N}$, whereas at CRF rates above 0.75 $\mathrm{kg} \cdot \mathrm{m}^{-3} \mathrm{~N}$ no significant change in growth index or overall appearance occurred. Therefore, the adequate CRF application range appears to have been achieved but not exceeded for the CRF rates applied to 'Palace Purple' coral bells in this study. Rose of sharon growth index and overall appearance increased with increasing CRF rate, with no difference among higher CRF rates, indicating adequate fertilization occurred during the study.

Given the growth index and overall appearance response of nursery crops to the applied CRF rates, use of species-specific CRF rates may prevent nutrient disorder symptoms at the nursery. For example, visual nutrient deficiency symptoms were observed at low CRF rates for 'Palace Purple' coral bells, bigleaf hydrangea, 
Table 2. Regression equations and $R^{2}$ values for significant growth index versus time grown with six rates of nitrogen $(N)$ incorporated from an 8-9 month release $19 \mathrm{~N}-2.6 \mathrm{P}-10.8 \mathrm{~K}$ plus minors controlled-release fertilizer (CRF) incorporated at planting for five nursery crops outdoors from May to Sept. 2013 in the Niagara region of Ontario, Canada.

\begin{tabular}{|c|c|c|}
\hline CRF rate $\left(\mathrm{kg} \cdot \mathrm{m}^{-3} \mathrm{~N}\right)^{\mathrm{z}}$ & Regression equation $^{\mathrm{y}}$ & $R^{2}$ \\
\hline \multicolumn{3}{|l|}{ Bigleaf hydrangea } \\
\hline 0.15 & $\mathrm{Y}=37.2-0.21 \mathrm{X}+0.002 \mathrm{X}^{2}$ & 0.35 \\
\hline 0.45 & $\mathrm{Y}=17.9-0.06 \mathrm{X}+0.005 \mathrm{X}^{2}$ & 0.79 \\
\hline 0.75 & $\mathrm{Y}=1.3+0.93 \mathrm{X}$ & 0.79 \\
\hline 1.05 & $\mathrm{Y}=5.2+1.1 \mathrm{X}$ & 0.85 \\
\hline 1.35 & $\mathrm{Y}=6.4+1.2 \mathrm{X}$ & 0.75 \\
\hline 1.65 & $\mathrm{Y}=8.1+1.0 \mathrm{X}$ & 0.82 \\
\hline \multicolumn{3}{|l|}{ 'Green Velvet' boxwood } \\
\hline 0.75 & $\mathrm{Y}=2.8-0.07 \mathrm{X}+0.0008 \mathrm{X}^{2}$ & 0.57 \\
\hline 1.05 & $\mathrm{Y}=2.1-0.03 \mathrm{X}+0.0007 \mathrm{X}^{2}$ & 0.61 \\
\hline 1.35 & $\mathrm{Y}=0.91+0.08 \mathrm{X}$ & 0.50 \\
\hline 1.65 & $\mathrm{Y}=3.2-0.04 \mathrm{X}+0.0009 \mathrm{X}^{2}$ & 0.63 \\
\hline \multicolumn{3}{|l|}{ 'Magic Carpet' spirea } \\
\hline 0.15 & $\mathrm{Y}=17.9-0.12 \mathrm{X}+0.001 \mathrm{X}^{2}$ & 0.35 \\
\hline 0.45 & $Y=15.9-0.004 X+0.002 X^{2}$ & 0.76 \\
\hline 0.75 & $\mathrm{Y}=9.1+0.34 \mathrm{X}$ & 0.68 \\
\hline 1.05 & $Y=0.89+0.52 X$ & 0.86 \\
\hline 1.35 & $Y=1.4+0.53 X$ & 0.79 \\
\hline 1.35 & $Y=5.0+0.58 X$ & 0.87 \\
\hline \multicolumn{3}{|l|}{ 'Palace Purple' coral bells } \\
\hline 0.45 & $\mathrm{Y}=3.2+0.41 \mathrm{X}$ & 0.84 \\
\hline 0.75 & $Y=15.6+0.04 X+0.003 X^{2}$ & 0.84 \\
\hline 1.05 & $Y=-2.7+0.51 X$ & 0.73 \\
\hline 1.35 & $\mathrm{Y}=3.1+0.53 \mathrm{X}$ & 0.87 \\
\hline 1.65 & $Y=3.0+0.56 X$ & 0.81 \\
\hline \multicolumn{3}{|l|}{ Rose of sharon } \\
\hline 0.15 & $\mathrm{Y}=6.9+0.93 \mathrm{X}-0.005 \mathrm{X}^{2}$ & 0.77 \\
\hline 0.45 & $\mathrm{Y}=1.8+1.1 \mathrm{X}-0.006 \mathrm{X}^{2}$ & 0.64 \\
\hline 0.75 & $\mathrm{Y}=-4.6+1.2 \mathrm{X}$ & 0.44 \\
\hline 1.05 & $Y=-15.7+2.5 X-0.01 X^{2}$ & 0.67 \\
\hline 1.35 & $Y=3.5+0.87 X$ & 0.50 \\
\hline 1.65 & $\mathrm{Y}=1.5+1.4 \mathrm{X}$ & 0.77 \\
\hline
\end{tabular}

${ }^{\mathrm{z}} \mathrm{l} \mathrm{kg} \cdot \mathrm{m}^{-3}=0.0624 \mathrm{lb} / \mathrm{ft}^{3}$.

'Regression analyses with extra sum-of-squares $F$ tests were used to estimate regression parameters for the best-fit regression model.

and 'Magic Carpet' spirea. As the leaf dry weight of 'Palace Purple' coral bells was positively correlated to both $\mathrm{N}$ and $\mathrm{P}$ concentrations, the small, dark red-purple leaves observed at $0.15 \mathrm{~kg} \cdot \mathrm{m}^{-3} \mathrm{~N}$ in Sept. 2013 may have been the result of a deficiency in $\mathrm{N}$ (i.e., low green pigment levels may have increased the visibility of the purple pigments), P (i.e., increasing purple pigment levels), or a combination of both. The light green leaf color and purple leaf margins observed for bigleaf hydrangea at 0.15 $\mathrm{kg} \cdot \mathrm{m}^{-3} \mathrm{~N}$ may have been due to $\mathrm{N}$ and $\mathrm{P}$ deficiencies, respectively, as both the tissue $\mathrm{N}$ and $\mathrm{P}$ concentrations were positively correlated to leaf dry weight. The light yellow leaves observed for 'Magic Carpet' spirea at
CRF application rates recommended by the supplier may need to be adjusted and customized for individual nurseries and crops, to prevent nutrient disorders.

By considering the evaluated plant growth and quality characteristics, we determined the speciesspecific recommended CRF rates for the container-grown nursery crops in this study. We defined the highest CRF rate in the recommended range to be the rate above which no increase in growth index, shoot dry weight, leaf area, and overall appearance, or no nutrient disorder symptoms were observed. The lowest CRF rate in the recommended range was the rate below which plants were not marketable or were showing nutrient disorder symptoms. If no difference was identified between the highest and lowest recommended CRF application rates, a single recommended CRF rate, rather than a recommended range was identified. Given these parameters, the responses of individual crops varied. Rose of sharon plants were not marketable below $1.05 \mathrm{~kg} \cdot \mathrm{m}^{-3} \mathrm{~N}$ and no increase in rose of sharon leaf area was observed above $1.35 \mathrm{~kg} \cdot \mathrm{m}^{-3} \mathrm{~N}$. Bigleaf hydrangea, 'Magic Carpet' spirea, and 'Palace Purple' coral bells were not marketable below $0.75 \mathrm{~kg} \cdot \mathrm{m}^{-3} \mathrm{~N}$ and 'Palace Purple' coral bells did not increase in overall appearance or leaf area above $0.75 \mathrm{~kg} \cdot \mathrm{m}^{-3} \mathrm{~N}$. Bigleaf hydrangea overall appearance did not increase above $1.35 \mathrm{~kg} \cdot \mathrm{m}^{-3} \mathrm{~N}$ and 'Magic Carpet' spirea growth index did not increase above $1.05 \mathrm{~kg} \cdot \mathrm{m}^{-3} \mathrm{~N}$. For 'Green Velvet' boxwood, a nutrient disorder was observed below 0.75 $\mathrm{kg} \cdot \mathrm{m}^{-3} \mathrm{~N}$, whereas above $1.35 \mathrm{~kg} \cdot \mathrm{m}^{-3}$ $\mathrm{N}$ shoot dry weight did not increase. Therefore, the recommended speciesspecific CRF rate was $0.75 \mathrm{~kg} \cdot \mathrm{m}^{-3} \mathrm{~N}$ for 'Palace Purple' coral bells, and the recommended CRF ranges were 1.05 to $1.35 \mathrm{~kg} \cdot \mathrm{m}^{-3} \mathrm{~N}$ for rose of sharon, 0.75 to $1.05 \mathrm{~kg} \cdot \mathrm{m}^{-3} \mathrm{~N}$ for 'Magic Carpet' spirea, and 0.75 to $1.35 \mathrm{~kg} \cdot \mathrm{m}^{-3}$ $\mathrm{N}$ for bigleaf hydrangea and the first season of 'Green Velvet' boxwood production. Our results confirm and build on previous research identifying wide-ranging nutritional requirements and species-specific CRF rate responses for container-grown nursery crops, such as an optimal CRF rate of 1.25 $\mathrm{kg} \cdot \mathrm{m}^{-3} \mathrm{~N}$ for 1-gal 'Magic Carpet' spirea, similar to our results (Agro and Zheng, 2014; Chong et al., 2004; 


\section{Research Reports}

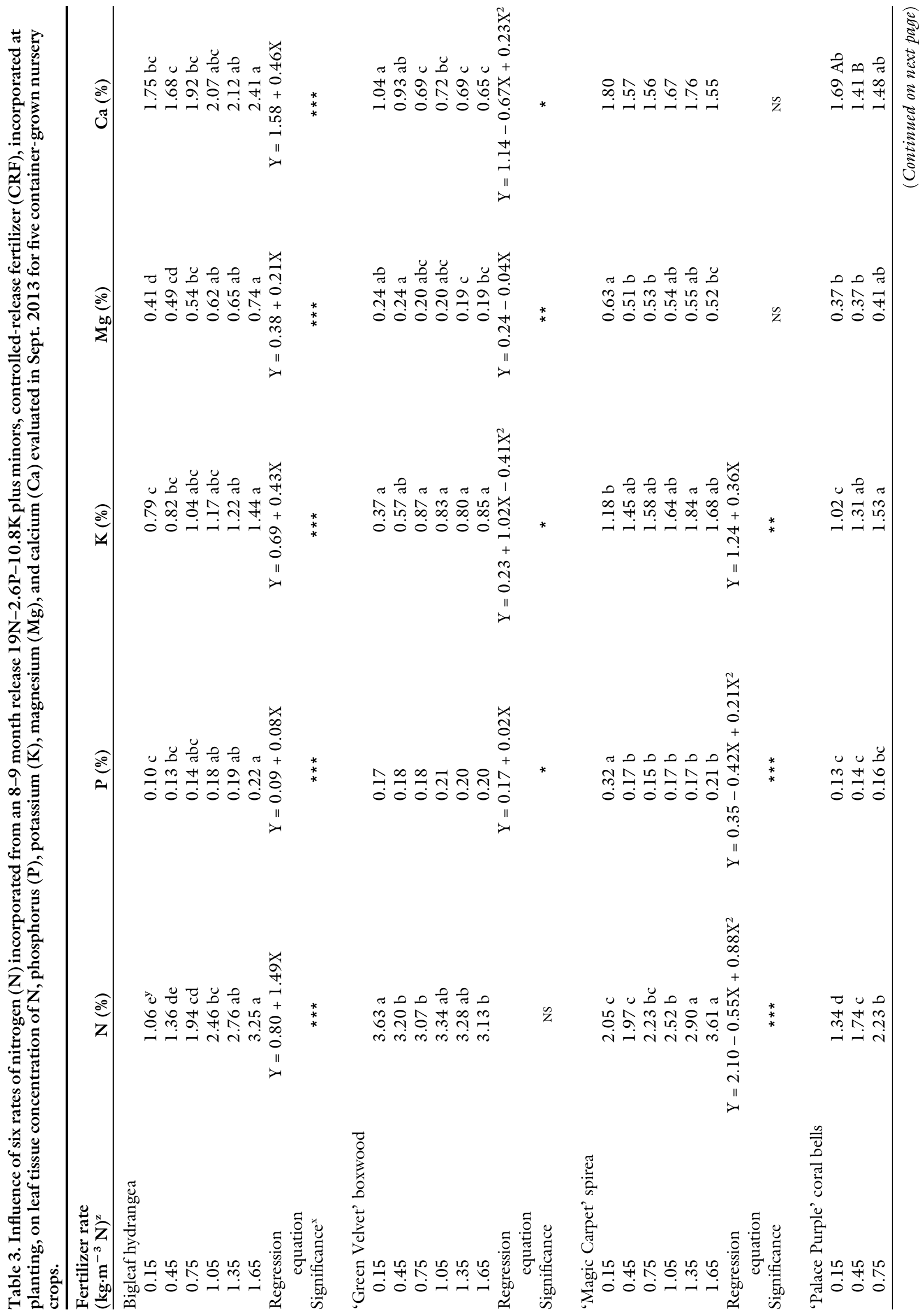




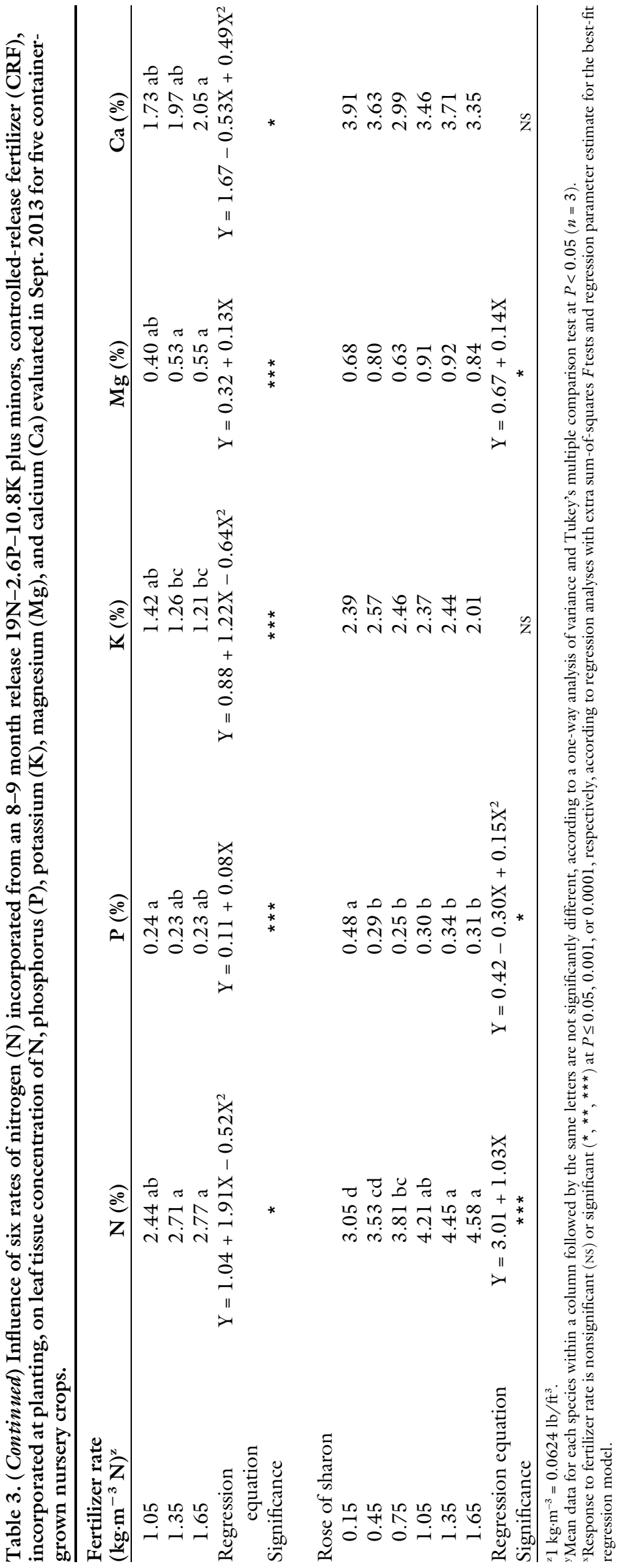

Scoggins, 2005; Worrall et al., 1987). These studies also showed that reductions in nutrient leaching were achieved when appropriate CRF rates were applied (Agro, 2014; Clark and Zheng, 2014).

Nutrient leaching from growing substrates in outdoor container nursery environments is influenced by climate, temperature, and production practices (Adams et al., 2013; Alam et al., 2009; Bilderback, 2002). Growing substrate nutrient status and nutrient leaching during this study were determined by leachate EC. The counterintuitive high leachate EC at low CRF rates in Sept. 2013 may have been caused by minimal leaching during the previous months or low nutrient uptake during the growing season, whereas low leachate EC at high CRF rates and lack of correlation between CRF rate and EC in Sept. 2013 suggested most nutrients had already been leached or used for plant growth (Alam et al., 2009). Despite a common industry perspective that a high CRF application will eliminate the need for an additional CRF application the following year, annual CRF applications would likely be needed for the crops grown at high CRF rates in this study. Frequently monitoring nutrient status may determine whether a midseason CRF top-dress application is required. Further temperate-climate research is needed to quantify nutrient status and nutrient leaching from growing substrates with incorporated CRFs during outdoor container nursery production.

Conditions of low fertility during nursery crop production can occur from either a low CRF application, relative to crop need, or as a result of excess nutrient leaching. When nursery crops are grown in conditions of low fertility, tissue nutrient analysis may not identify nutrient deficiencies by simply comparing readings to published tissue nutrient sufficiency standards and averages, as described by Bryson et al. (2014), Plank and Kissel (2006), and Jarrell and Beverly (1981). For example, in this study, rose of sharon plants were smaller at low vs. high CRF rates and no clear tissue nutrient deficiencies were observed, with $\mathrm{N}, \mathrm{P}, \mathrm{K}, \mathrm{Mg}$, and Ca levels at all CRF rates being within or above the rose of sharon nutrient sufficiency range described by 
Bryson et al. (2014). Therefore, leaf tissue nutrient concentration data should be considered in combination with critical observations of aboveground plant growth and appearance to manage nursery crop production. In addition, further research is needed to determine nutrient sufficiency standards for additional commonly grown nursery crops.

Under conditions of sufficient CRF application, growing substrate $\mathrm{pH}$ influences nutrient availability, which subsequently impacts nutrient uptake and plant growth. The growing substrate $\mathrm{pH}$ at all CRF rates in May 2013 , as evaluated by leachate $\mathrm{pH}$, was within the desired range for plant growth [i.e., 5.50-6.25 (Reed, 1996)]. For 'Green Velvet' boxwood, 'Magic Carpet' spirea, and 'Palace Purple' coral bells, $\mathrm{pH}$ of the growing substrate at $0.15,0.45$, and 0.75 $\mathrm{kg} \cdot \mathrm{m}^{-3} \mathrm{~N}$, as well as $\mathrm{pH}$ of bigleaf hydrangea and rose of sharon at 0.45 $\mathrm{kg} \cdot \mathrm{m}^{-3} \mathrm{~N}$, was greater than the upper limit for plant growth in a growing substrate [6.25 (Reed, 1996)]. The high growing substrate $\mathrm{pH}$ in Sept. 2013 was likely due to on-site irrigation water having a high alkalinity, as is common in Ontario (Zheng et al., 2011). At high CRF rates, the low growing substrate $\mathrm{pH}$ may have been caused by the CRF acidifying the root zone (Zheng et al., 2013). The influence of CRFs on root-zone $\mathrm{pH}$, as observed by correlations, presents an opportunity for fertilizer companies to develop CRFs specifically formulated to control growing substrate $\mathrm{pH}$ during nursery crop production. Appropriate CRF rates or ranges may be used to manage growing substrate $\mathrm{pH}$ levels to ensure plant access to nutrients throughout the growing season.

In conclusion, this study confirms that CRFs can be used as a management tool in containerized nursery crop production, and provides species-specific CRF rate recommendations for commonly grown nursery crops in a temperate climate. For the majority of crops in this study, overall appearance, growth index, plant height, leaf area, and shoot dry weight were greater at high vs. low CRF rates. The recommended species-specific CRF rate for outdoor, nursery crop production was $0.75 \mathrm{~kg} \cdot \mathrm{m}^{-3} \mathrm{~N}$ for 'Palace Purple' coral bells, and the recommended CRF ranges were 1.05 to $1.35 \mathrm{~kg} \cdot \mathrm{m}^{-3}$
$\mathrm{N}$ for rose of sharon, 0.75 to 1.05 $\mathrm{kg} \cdot \mathrm{m}^{-3} \mathrm{~N}$ for 'Magic Carpet' spirea, and 0.75 to $1.35 \mathrm{~kg} \cdot \mathrm{m}^{-3} \mathrm{~N}$ for bigleaf hydrangea and 'Green Velvet' boxwood. Further research is needed to determine species-specific management strategies and CRF application rate recommendations for additional nursery crops under temperateclimate production conditions.

\section{Literature cited}

Adams, C., J. Frantz, and B. Bugbee. 2013. Macro- and micronutrient-release characteristics of three polymer-coated fertilizers: Theory and measurements. J. Plant Nutr. Soil Sci. 176:76-88.

Agro, E.E. 2014. Optimum controlled release fertilizer rates for containerized nursery plant production in Ontario. MSc Thesis, Univ. Guelph, Guelph, ON, Canada.

Agro, E.E. and Y. Zheng. 2014. Controlled-release fertilizer application rates for container nursery crop production in southwestern Ontario, Canada. HortScience 49:1414-1423.

Alam, M.Z., C. Chong, J. Llewellyn, and G.P. Lumis. 2009. Evaluating fertilization and water practices to minimize $\mathrm{NO}_{3}-\mathrm{N}$ leachate from container-grown forsythia. HortScience 44:1833-1837.

Bilderback, T.E. 2002. Water management is key in reducing nutrient runoff from container nurseries. HortTechnology 12:541-544.

Birrenkott, B.A., J.L. Craig, and G.R. McVey. 2005. A leach collection system to track the release of nitrogen from controlled-release fertilizers in container ornamentals. HortScience 40:1887-1891.

Britton, W., E.J. Holcomb, and D.J. Beattie. 1998. Selecting the optimum slow-release fertilizer rate for five cultivars of tissue-cultured Hosta. HortTechnology 8:203-206.

Bryson, G.M., H.A. Mills, D.N. Sasseville, J.B. Jones, Jr., and A.B. Barker. 2014. Plant analysis handbook III: A guide to sampling, preparation, analysis, interpretation and use of results of agronomic and horticultural crop plant tissue. Macro-Micro Publishing, Athens, GA.

Cabrera, R. 1996. Using slow- and controlled-release fertilizers in container nursery crops. Rutgers Coop. Res. Ext., New Jersey Agr. Expt. Sta., Rutgers Univ. New Brunswick, NJ.

Cabrera, R. 1997. Comparative evaluation of nitrogen release patterns from controlledrelease fertilizers by nitrogen leaching analysis. HortScience 32:669-673.
Cabrera, R. 2003. Nitrogen balance for two container-grown woody ornamental plants. Sci. Hort. 97:297-308.

Chen, J., Y. Huang, and R.D. Caldwell. 2001. Best management practices for minimizing nitrate leaching from containergrown nurseries. Sci. World 1(S2):96-102.

Chen, Y., R.P. Bracy, A.D. Owings, and J.P. Quebedeaux. 2011. Controlledrelease fertilizer type and rate affect landscape establishment of seven herbaceous perennials. HortTechnology 21:336-342.

Chong, C., G. Lumis, P. Purvis, and A. Dale. 2004. Growth and nutrient status of six species of nursery stock grown in a compost-based medium with recycled nutrients. HortScience 39:60-64.

Clark, M.J. and Y. Zheng. 2014. Effect of fertilizer rate on plant growth and leachate nutrient content during production of sedum-vegetated green roof modules. HortScience 49:819-826.

Clark, M.J. and Y. Zheng. 2015. Speciesspecific fertilization can benefit container nursery crop production. Can. J. Plant Sci. 95:251-262.

Davidson, H., R. Mecklenburg, and C. Peterson. 1988. Nursery management. Prentice Hall, Englewood Cliffs, NJ.

Environment Canada. 2013. Climate: Hourly data. 29 Jan. 2014. <http:// climate.weather.gc.ca/climateData/ hourlydata_e.html? timeframe $=1 \&$ Prov $=$ ONT\&Station ID $=44283 \&$ hlyRange $=$ 2005-11-23|2014-04-21\&Year $=2013$ $\&$ Month $=6 \&$ Day $=21>$.

Griffin, J.J., S.L. Warren, F.A. Blazich, and T.G. Ranney. 1999. Nitrogen nutrition of containerized Thuja $\times$ 'Green Giant'. J. Environ. Hort. 17:76-79.

Hicklenton, P.R. and K.G. Cairns. 1992. Solubility and application rate of controlledrelease fertilizer affect growth and nutrient uptake in containerized woody landscape plants. J. Amer. Soc. Hort. Sci. 117:578583.

Jarrell, W.M. and R.B. Beverly. 1981. The dilution effect in plant nutrition studies. Adv. Agron. 34:197-224.

Lumis, G. and L. Taurins. 2000. Container mix $\mathrm{pH}$ and the effect of Scotts controlled release fertilizers in altering $\mathrm{pH}$ increase. 4 Feb. 2014. <http://www. landscapetrades.com $/ 2000 / 07 /$ container-mix-ph-and-the-effect-ofscotts-controlled-release-fertilizers-inaltering-ph-increase $>$.

Majsztrik, J.C., A.G. Ristvey, and J.D. Lea-Cox. 2011. Water and nutrient management in the production of containergrown ornamentals. Hort. Rev. 38: 253-296. 
Oliet, J., R. Planelles, M.L. Segura, F. Artero, and D.F. Jacobs. 2004. Mineral nutrition and growth of containerized Pinus halepensis seedlings under controlledrelease fertilizer. Sci. Hort. 103:113-129.

Plank, C.O. and D.E. Kissel. 2006. Plant analysis handbook-Commonly found nutrient concentration ranges. 19 Feb. 2014. <http://aesl.ces.uga.edu/publications/ plant/contable.asp>.

Reed, D.W. 1996. A grower's guide to water, media, and nutrition for greenhouse crops. Ball Publishing, Batavia, IL.

Ruter, J.M. 1992. Influence of source, rate, and method of applicating [sic] controlled release fertilizer on nutrient release and growth of 'Savannah' holly. Fert. Res. 32:101-106.

Scoggins, H.L. 2005. Determination of optimum fertilizer concentration and corresponding substrate electrical conductivity for ten taxa of herbaceous perennials. HortScience 40:1504-1506.

Statistics Canada. 2013. Table00010057-Nursery tree and plant production. 4 Feb. 2014. <http://www5.statcan.gc. $\mathrm{ca} /$ cansim/a26? lang=eng\&retrLang=eng \&id $=0010057 \&$ paSer $=\&$ pattern $=\& s t B y$ $\mathrm{Val}=1 \& \mathrm{p} 1=1 \& \mathrm{p} 2=38 \&$ tabMode $=$ data Table\&csid $>$.
Stroup, W.W., S.A. Adams, and E.T. Paparozzi. 1998. Statistical design and analysis of producer/consumer evaluations to assess plant quality. HortScience 33:197-202.

Timmer, V.R. and A.S. Aidelbaum. 1996. Manual for exponential nutrient loading of seedlings to improve outplanting performance on competitive forest sites. Northern Ontario Dev. Agreement/Northern For. Program Tech. Rpt. No. TR-25. Natural Res. Canada, Can. For. Serv. Sault Ste. Marie, ON, Canada.

U.S. Department of Agriculture. 2006. Floriculture and nursery crop yearbook 2006. 4 Feb. 2014. <http://usda. mannlib.cornell.edu/MannUsda/ viewStaticPage.do?url=http://usda0l library.cornell.edu/usda/ers/./98004/ 2006/index.html>.

Worrall, R.J., G.P. Lamont, and M.A. O'Connell. 1987. The growth response of container-grown woody ornamentals to controlled-release fertilizers. Sci. Hort. 32:275-286.

Wright, R.D. 1986. The pour through nutrient extraction procedure. HortScience 21:227-229.

Yeager, T. and G. Cashion. 1993. Controlledrelease fertilizers affect nitrate nitrogen runoff from container plants. HortTechnology 3:174-177.

Yeager, T., J. Million, C. Larsen, and B. Stamps. 2010. Florida nursery best management practices: Past, present and future. HortTechnology 20:82-88.

Yeager, T., R. Wright, D. Fare, C. Gilliam, J. Johnson, T. Bilderback, and R. Zondag. 1993. Six state survey of container nursery nitrate nitrogen runoff. J. Environ. Hort. 11:206-208.

Zheng, Y., D.F. Cayanan, and M. Dixon. 2010. Optimum feeding nutrient solution concentration for greenhouse potted miniature rose production in a recirculating subirrigation system. HortScience 45:13781383.

Zheng, Y., K. Vinson, and M. Dixon. 2011. Acidify irrigation water for potted nursery crop production. Landscape Ontario Mag. 29(12):58.

Zheng, Y., M.J. Clark, E. Agro, and K. Vinson. 2013. Fertilizer can be used as a management tool in container nursery production. 6 Feb. 2014. <http:// vinelandresearch.com/sites/default/ files/2013_nursery_fertilizer_report. pdf $>$. 